\title{
POLITICAL PARTY FUNDING IN THE 2004 ELECTION
}

\author{
By \\ Dirk Kotzé
}

\begin{abstract}
Dr Dirk Kotzé is Senior Lecturer in the Department of Political Sciences, University of South Africa

PO Box 392 Unisa 0003

Tel: +27 (0) 12429 6512; +27 082 7897401; Fax: +27 (0) 124293221

email: kotzedj@unisa.ac.za
\end{abstract}

\begin{abstract}
The paper concentrates on public funding of political parties during the 2004 general election. The fact that no regulatory framework exists for private funding is detrimental to the proper regulation of public funding so the Institute for Democracy in South Africa has launched a court action to compel parties to disclose their private sources. International experiences and comparisons are used as a point of reference to analyse the South African situation. South Africa's framework for party funding consists of the African Union and Southern African Development Community agreements, the Public Funding of Represented Political Parties Act and its Regulation, and the Electoral Code of Conduct. South African parties represented in the national and provincial legislatures are funded on the basis of a formula consisting of proportional and equitable components by a fund appropriated mainly by Parliament and managed by the Independent Electoral Commission (IEC). The parties' accountability to the IEC is hampered by a lack of statutory powers.
\end{abstract}

\section{INTRODUCTION}

The funding of political parties - especially at election times - is an unavoidable but controversial dimension of any functional democracy. There is a general perception that access to funds translates into more electoral profits. Hence, parties with fewer financial resources than the others are ostensibly systematically disadvantaged. The most radical view is, therefore, that a multiparty and democratic dispensation will reach an optimal point where party funding is most equitably distributed. In practice, the financial resources of parties are always unequally spread, and this should not be perceived as inherently anti-democratic.

A fundamental question is, however, what the balance should be between self-generated funds and public funds. Self-generated funds are often divided into domestically-raised funds and funds from abroad, as well as 'hard' and 'soft' money (depending on the nature of private donations). Public funds can serve as a balancing 
factor, to act as a substitute for a lack of self-generated private funds, but they will never be an equaliser of financial resources.

In this paper the focus is primarily on public funding in South Africa specifically insofar as it applied to the April 2004 general election. It is a generally accepted notion that public funding is inextricably linked to the parties' private funding, especially insofar as it affects the regulatory or oversight mechanisms devised to enhance public accountability. The 2004 election campaign witnessed a concerted effort by the Institute for Democracy in South Africa (Idasa) to intervene in this respect.

\section{IDASA's CALL FOR TRANSPARENCY}

In late 2003 Idasa instituted a court application against the African National Congress (ANC), the Democratic Alliance (DA), the Inkatha Freedom Party (IFP), the New National Party (NNP) and the African Christian Democratic Party (ACDP). (The ACDP has since been removed from the list.) The application was made in terms of the Promotion of Access to Information Act 2002, in order to gain access to the records of private donations to the parties and to their other sources of income. All the legal preparations for the court appearance were completed by the end of 2004 and court hearings were expected to commence in early 2005 in the Cape High Court (interview, Judith February: 2004).

Idasa started with a campaign in 1997 to enhance the parties' transparency in the absence of any specific legislation regulating private funding for political parties. In the near future South Africa will have to demonstrate its adherence to the African Union Convention on Preventing and Combating Corruption, adopted on 11 July 2003 in Maputo. Article 10 of the convention reads:

Each State Party shall adopt legislative and other measures to:

a) Proscribe the use of funds acquired through illegal and corrupt practices to finance political parties; and

b) Incorporate the principle of transparency into funding of political parties.

Idasa's main argument is based on the constitutional principle of political equality and its concern that undisclosed private funding can encourage corruption. Equality is relevant insofar as everyone should have an equal opportunity, including donations, to influence political processes through participation. South Africa, according to Idasa, is, however, a developing country with systemic socio-economic disparities and serious demographic differences. Hence unregulated party funding would have a real potential to compromise the democratic nature of multiparty competition and influence decision-making. Idasa recognises that regulation will not be the panacea for all the problems but believes 'that transparency is just one 
instrument in a family of laws and policies that must be employed to deal with the issues that interlock around the relationship between democracy and capital' (Idasa nd).

Idasa applauded the announcement made by AngloGold in December 2003 that it would voluntarily release details of its donations of R3,2-million to political parties for the 2004 elections. 'The advantage of knowing is that an assessment of policy decisions can be made with all the relevant knowledge. Being able to make an informed choice is surely a critical element in a healthy democracy' (Idasa).

AngloGold's example was followed by Standard Bank (with a R5-million donation) and the Liberty Group (R1,5-million), the latter funding almost all the parties represented in Parliament (Mamaila 2002, p 2; Msomi 2004). Sanlam also announced that it had donated R1-million each to the ANC and the NNP. Early in 2004 it emerged that the mining magnate, Brett Kebble, of Johannesburg Consolidated Investments, had donated R500 000 to the ANC's Western Cape provincial structures. Earlier, he had allegedly made a R400 000 donation to the governing NNP in the Western Cape in exchange for their helping a developer secure rights to develop a golf estate in Plettenberg Bay (Msomi 2004; Wa Afrika, Jurgens \& Bezuidenhout 2004). Another mining investor, Tokyo Sexwale, of Mvelaphanda, made public donations to both former presidents Nelson Mandela and F W de Klerk (Nduru 2004). Groups like AngloGold, Liberty and Standard Bank developed criteria for their allocation of donations, which contribute towards public accountability (Msomi 2004), but the parties still refuse to reciprocate with disclosures from their side.

Idasa's argument for public disclosure rests also on a concern about the potential for corruption. It considers the absence of any regulation of private funding a gap in an otherwise strong anti-corruption public apparatus. 'Our advocacy is based on the premise that where there is no regulation of private funding to political parties and donors are able to give as much they wish, in secret, the opportunity for corruption increases'.

The overall objectives of the Idasa campaign - supported by the Institute for Security Studies, the Open Democracy Advice Centre, the Southern African Catholic Bishops' Conference, the South African Council of Churches and The Black Sash are to:

- constrain undue influence on political parties, public representatives and the governing party;

- lessen the likelihood of, or at least reduce the incidence of, patronage;

- expose patronage appointments in the public service and bring to light the relationship between certain Government decisions and large private donations. 
In the next section we compare briefly party funding and guidelines and options based on international experiences.

\section{INTERNATIONAL COMPARISONS AND FRAMEWORKS}

The International Institute for Democracy and Electoral Assistance (IDEA) recently published comparative research on party funding (Austin \& Tjernström 2003) and concluded that it raised two main questions: how much information about party finance should the voter be entitled to have and to what extent should public money be used to support and develop political parties?

Answers to these questions can be found in the following four broad funding options derived from international experience (Austin \& Tjernström 2003, pp 10-13):

a) Autonomy option: Political parties are voluntary associations entitled to unregulated privacy of their internal organisation and financial management. Competition between political parties serves as a guarantee of self-regulation and provides for self-correcting mechanisms.

b) Transparency option: Voters have the right to know how parties are funded. The regulatory power of competition is not sufficient and the public must serve as a watchdog.

c) Advocacy option: A public agency is required which can monitor, control and enforce sets of rules regulating party funding. It is also required to be a public watchdog.

d) Diversified regulation option: This combines benign neglect, precise regulation, public incentives and occasional sanctions.

In view of the fact that political parties are considered an important component of civil society and that multiparty contestation for the status and privilege of government should occur without any government or state interference, private funding is generally accepted. Public funding, on the other hand, is more contested as a political practice. Austin \& Tjernström (2003, pp 4-8) summarise the reasons for and against it in the following points: Public funding is deemed to be a necessary cost of democracy. It is also justified as the bridge between voluntary, private donations and required or necessary spending by political parties. Public funds are considered as a means to level the playing field between parties, and which will arguably enhance parties' chances to be elected.

Opponents of public funding fear that parties may lose their independence and become reliant on funding. There are also differences of opinion about the distribution formula for the allocation of funds and public funding is generally unpopular with the public. A compromise is reached in the form of regulatory frameworks, such as limits (mainly on expenditures, disclosure of income and bans on sources of funding). Banned sources tend to be anonymous donations, foreign 
donations, donations from public sector contractors, corporate donations and trade union donations. Regulations on public funding pertain mainly to a disclosure of expenditure and prohibitions on the use of funds.

The frameworks within which party funding in South Africa have to be conducted are: the African Union (AU) Convention on Preventing and Combating Corruption, adopted in Maputo, 11 July 2003; the SADC Principles and Guidelines Governing Democratic Elections, SADC summit, Mauritius, August 2004; the Public Funding of Represented Political Parties Act 1997, and the Regulation under section 10(1) of the Act, 1998; and The Electoral Code of Conduct, Schedule 2 s 99 of the Electoral Act 73 of 1998.

The AU Convention includes party funding in the context of corruption and related offences. The relationship between the two is explained in terms of undue advantage or improper influence, which is more relevant in the case of private funding than of public funding. In Article 4(1)(f) acts of corruption in this respect are described as:

the offering, giving, solicitation or acceptance directly or indirectly, or promising of any undue advantage to or by any person who asserts or confirms that he or she is able to exert any improper influence over the decision making of any person performing functions in the public or private sector in consideration thereof, whether the undue advantage is for himself or herself or for anyone else, as well as the request, receipt or the acceptance of the offer or the promise of such an advantage, in consideration of that influence, whether or not the influence is exerted or whether or not the supposed influence leads to the intended result

AU 2003, p 8

Article 9(2) of the South African Electoral Code of Conduct appears to have the same objective. It prohibits any person from offering any inducement or reward to another person to join or not to join a party; to attend or not attend a public meeting, march, demonstration, rally or other public political event; to vote or not to vote, or to vote or not to vote in a particular way; or to refuse a nomination as a candidate or to withdraw as a candidate (Electoral Act 1998: Schedule 2, s 99). These forms of prohibited conduct can include the use of funds - and in South Africa public funds are an important component of the parties' electoral resources.

SADC has been slightly more specific in its recently adopted Principles and Guidelines, though they pertain only to election observation. One of the guidelines, 'to determine the nature and scope of election observation', is set in paragraph 4.1.6: 'Where applicable, funding of political parties must be transparent and based on an agreed threshold in accordance with the laws of the land' (SADC 2004, p 2). This stipulation is ambiguous because it does not specify the public or private nature of the funding. One can assume that it includes private funding, but it is not clear whether it also includes public funding. Though the SADC guidelines are 
supposedly directed at setting standards for the region, this stipulation is not formulated in a prescriptive format: 'in accordance with the laws of the land'. South Africa, for example, does not have a statutorily agreed threshold. Therefore the SADC stipulation is weak - if the qualification 'where applicable' is also added and will hardly contribute to greater transparency.

Reference to a threshold is an interesting addition to the discussion about party funding. Even in developed economies and consolidated democracies there is increasing support for the imposition of limitations on the amount of money spent by political parties. For example, at the $3^{\text {rd }}$ European Conference of Specialised Services in the Fight Against Corruption, held in Madrid in October 1998, the participants concluded that at national level one of the principles to include in European conventions on corruption, is to 'impose an upper limit on political parties' and election campaigns' expenditure' (Madrid 1998, p 2). In 2001 the Parliamentary Assembly of the Council of Europe adopted Recommendation 1516, 'Financing of political parties', which included this principle (Parliamentary Assembly 2001, p 2). Another recommendation by the Council's Committee of Ministers followed in 2003. Article 1 of Recommendation 4 (2003) states that the 'state should provide support to political parties. State support should be limited to reasonable contributions. State support may be financial.' The recommendation suggests limits on expenditure: 'States should consider adopting measures to prevent excessive funding needs of political parties, such as, establishing limits on expenditure on electoral campaigns.' States should require all political parties to specify all the donations they have received (Committee of Ministers 2003, pp 2-4). The forty-six members of the council, therefore, gradually move towards a highly regulated funding regime for political parties.

The relevance for South Africa is that, in view of the closer scrutiny of elections in general and the greater emphasis on 'good governance', which includes anticorruption and anti-fraud measures and early attempts at setting standards for the African continent and Southern Africa in particular, one can expect increasing attention to be paid to party funding. International comparisons indicate that funding is, globally, a delicate issue, and that Southern and South Africa do not necessarily lag behind in measures to improve its regulation. In the next section the focus is specifically on South African regulations applied in the 2004 general election.

\section{South African Funding Regulations}

Public funding of political parties in South Africa is regulated by the Public Funding of Represented Political Parties Act 103 of 1997, and the Regulation under Section 10(1) of the Public Funding of Represented Political Parties Act 1997 (Regulation R117, 1998), issued on 20 November 1998.

Section 236 of the Constitution of 1996 stipulates that to 'enhance multi-party democracy, national legislation must provide for the funding of political parties 
participating in national and provincial legislatures on an equitable and proportional basis'.

Article 2 of the Act provides for the establishment of the Represented Political Parties Fund. The fund's money will come from allocations made annually by Parliament, from contributions and donations made to the fund coming from any sources, from interest earned on moneys deposited and invested, and from any other sources.

Table 1 reflects the allocations from Parliament received by the fund since the 1998/1999 financial year.

Table 1

\begin{tabular}{|c|c|c|}
\hline Financial Year & Parliamentary Allocation (Rands) & Percentage Increase \\
\hline $1998 / 1999$ & 53000000 & - \\
\hline $1999 / 2000$ & 55650000 & 5,0 \\
\hline $2000 / 2001$ & 57880000 & 4,0 \\
\hline $2001 / 2002$ & 60983000 & 5,36 \\
\hline $2002 / 2003$ & 63683000 & 4,43 \\
\hline $2003 / 2004$ & 66653000 & 4,66 \\
\hline
\end{tabular}

The following interest was earned by the fund (in Rands):

$\begin{array}{rr}1998 / 1999 & 463589 \\ 1999 / 2000 & 2883194 \\ 2000 / 2001 & 2606610 \\ 2001 / 2002 & 526659 \\ 2002 / 2003 & 617695 \\ 2003 / 2004 & 442985\end{array}$

SOURCE: IEC 2001, pp 40, 44; IEC 2002A, pp 56, 62; IEC 2002в, pp 58, 64; IEC 2002C, pp 58, 64; IEC 2003, pp 56, 61; IEC 2004, pp 70, 74

According to officials of the Independent Electoral Commission (IEC) responsible for the fund's management, it has not yet received any donations or any other forms of contributions. A few small return payments made by a number of recipient parties constitute the remainder of the fund's income (interview, Chaplog-Louw \& Hendrickse 2004). 
According to the Act, the fund is managed and administered by the IEC's chief electoral officer in her capacity as the commission's head of administration. She is the fund's accounting officer and chief executive officer. In practice, the fund is managed in the IEC's Financial Management Department and specifically in its section Budget and Political Funding. This department accounts for its management functions to the IEC's Chief Financial Officer, who is accountable to the commission's Chief Executive Officer (interview, Chaplog-Louw \& Hendrickse 2004).

Article 5(1)(b) of the Act determines that the moneys allocated from the fund to a political party 'may be used for any purposes compatible with its functioning as a political party in a modern democracy'. They include the following (article $5(1)(b)(i-v i))$ :

- The development of the political will of the people.

- Bringing the political parties' influence to bear on the shaping of public opinion.

- Inspiring and furthering political education.

- Promoting active participation by individual citizens in political life.

- Exercising an influence on political trends.

- Ensuring continuous, vital links between the people and organs of state.

Article 5(3)(a-d) identifies the use of moneys excluded from public funding, namely:

- moneys used to directly or indirectly pay any benefit to a member of any legislature or anyone who holds any other office of profit in any sphere of government;

- financing anything in contravention of a code of ethics in any of the legislatures;

- moneys used for business purposes or to acquire immovable property, except property used for ordinary party political purposes;

- any other purpose which is incompatible with a political party's functioning in a modern democracy.

The question is whether these moneys can be used for election purposes. ChaplogLouw and Hendrickse (2004) interpret the Act in strict legal terms as not explicitly excluding electioneering from the purposes for which funding may be used. No specific reference is made in the Act to elections. In practice, the parties are using the allocated moneys for election campaigning.

The Act makes one specific reference to the use of money for elections: in article 9(3)(a) and (b) it determines that not more than twenty-one days before an election of Parliament and/or a provincial legislature, the political parties represented in those legislatures which have received public funding have to close their accounts funded by public money. Not more than one day before the election they must repay to the fund (and therefore to the IEC) their unspent balances as 
they were twenty-one days before election day. Within fourteen days of the election they have to submit an audited statement of their accounts to the IEC.

In practice, this means that parties can use their public funds for election campaigning up to three weeks before election day. Most of the parties participating in the 2004 election campaigned for between eight and ten weeks, which means that for the majority of the period public funds could be used. The IEC is unsure about the rationale for the twenty-one-day cut-off period, except to guess that it might serve as a gesture to create a more level playing field for represented and unrepresented political parties (interview Chaplog-Louw \& Hendrickse 2004). Such a rationale would be valid only if the election campaign period were very short and all the parties had equitable access to private funding. A level playing field is merely a constitutional principle, but, in reality, the differing strengths and levels of popular support for parties are also reflected in their resources and financial capacities. Though financial resources are indispensable to modern-day election campaigns, no direct correlation has yet been established between spending on campaigns and electoral support. A level playing field is therefore neither a political reality nor an absolute prerequisite for a fair election.

Reference was made in the discussion of the Act's Article 5(3)(a-d) to the uses excluded from public funding. This raises the question of who is responsible for enforcing parties' compliance with the Act, and who, therefore, determines violations of these prescriptions. The IEC's approach is to leave the matter in the hands of each party's external auditors, whose reports must indicate whether the allocated moneys were used in accordance with the Act. The IEC relies on the Auditor General's review of all these reports to identify any violations. Between 1998 and 2004 no such violations were reported (interview, Chaplog-Louw \& Hendrickse 2004).

Parties receive public funding based on a particular allocation formula. These formulae are often contested and IDEA (Austin \& Tjernström 2003, p 9) has identified them as one of the problem areas in public funding. In South Africa, the Act stipulates two components for the formula:

the principle of proportionality based on three variations, namely a party's proportional representation in the National Assembly, or the provincial legislatures, or a combination of both. [It is important to note that local authorities are excluded.]

and

the principle of equity based on the following two variations, namely:

a) a fixed threshold for a minimum allocation to each of the parties represented in a legislature, or

b) a weighted scale of representation for an allocation to each of the political parties represented in a legislature [excluding local legislatures]. 
The Regulation (1998) specified the legislative provisions in more details. Of the total amount of funding allocated to the parties, 90 per cent is distributed in terms of proportionality and 10 per cent in terms of equity. For the 2004/2005 financial year this amounts to R63 759,40 (proportionality) and R7 084 443,60 (equity). The 90:10 distribution principle was decided upon by the joint parliamentary committee responsible for the Regulations issued in terms of the Act. The IEC did not play any role in determining this ratio.

The Regulation (1998) determines that proportional allocation is calculated by dividing the 90 per cent of the total amount among the participating parties in all the national and provincial legislatures in accordance with the number of seats awarded to each participating party in the National Assembly and the provincial legislatures jointly. (It therefore uses the third option mentioned in the Act.) The formula is, therefore: number of representatives per party (National Assembly plus all provinces) $\div 830$. For example, after the 2004 election the African Christian Democratic Party received six National Assembly seats and eight provincial legislature seats (Western Cape 2, KZN 2, Limpopo 1, Gauteng 1, Northern Cape 1, Free State 1). Therefore its proportional funding allocation is $(14 \div 830) \times 63759992,40$ $=$ R1 075 469,75.

The equitable allocation of 10 per cent is based on a fixed threshold and is determined by the following two steps:

a) the 10 per cent of the total amount is divided amongst the nine provinces in proportion to the number of seats in each provincial legislature, and

b) the allocation per province is divided equally between the represented parties in that provincial legislature.

This can be illustrated by looking at the allocation in the 2004/ 2005 financial year:

Step 1: Proportional Allocation Amongst Provinces (see Table 2)

The formula is (seats per province $\div 430$ - the total number of seats in all the provincial legislatures) x R7 084444 (the 10\% allocation).

An example is the Western Cape: $(42 \div 430) \times 7084444=\mathrm{R} 691969$ in total for all the parties in the legislature.

Step 2: Equal Allocation Within Provinces (see Table 3)

The intervals at which these allocations are paid to the parties are important for the purpose of planning a party's use of the moneys for elections. The Act and Regulation determine that payments must be made in four equal instalments, each 
within three months of the previous payment. The first instalment must be paid within four weeks of the beginning of the financial year. The fund's financial year is from 1 April to 31 March. In practice, the instalments are therefore paid in April, July, October and January.

Table 2

\begin{tabular}{|l|c|c|}
\hline Province & $\begin{array}{c}\text { Percentage of Seats } \\
(\mathbf{\%})\end{array}$ & $\begin{array}{c}\text { Allocation per Province } \\
\text { (Rands) }\end{array}$ \\
\hline Western Cape & 9,767 & 691968,91 \\
\hline Limpopo & 11,395 & 807297,06 \\
\hline Eastern Cape & 14,651 & 1037953,36 \\
\hline Gauteng & 16,977 & 1202707,87 \\
\hline KZN & 18,605 & 1318036,02 \\
\hline Northern Cape & 6,977 & 494263,51 \\
\hline North West & 7,674 & 543689,86 \\
\hline Mpumalanga & 6,977 & 494263,51 \\
\hline Free State & 6,977 & 494263,51 \\
\hline
\end{tabular}

Table 3

\begin{tabular}{|l|c|c|}
\hline Province & $\begin{array}{c}\text { Number of Represented Parties } \\
\text { per Province }\end{array}$ & $\begin{array}{c}\text { Allocation per Party } \\
\text { (Rands) }\end{array}$ \\
\hline Western Cape & $6(691968.01 \div 6)$ & 115328.15 \\
\hline Limpopo & 4 & 201824.27 \\
\hline Eastern Cape & 4 & 259488.34 \\
\hline Gauteng & 8 & 150338.48 \\
\hline KZN & 6 & 219672.67 \\
\hline Northern Cape & 6 & 82377.25 \\
\hline North West & 4 & 135922.46 \\
\hline Mpumalanga & 5 & 164754.50 \\
\hline Free State & 4 & 123565.88 \\
\hline
\end{tabular}


Taking into account the 21-day restriction placed on the use of public funds and the timing of these instalments, the election date of 14 April 2004 had the following implications:

a) Funding for the election was given in the 2003/2004 financial year, because the parties had to close their public funding accounts by 25 March 2004 and thereafter could not use any of the funds for election purposes.

b) Parties could not receive the first instalment in the 2004/2005 financial year on 1 April 2004 (ie, before the election) but had to wait until after the election results were certified.

c) The April instalment was therefore calculated on the basis of the 2004 election results.

Michael Hendrickse of the IEC highlights a complex legal implication. According to Article 5(1)(a) of the Act 'every political party is entitled to be allocated moneys from the fund for any financial year that it is represented' in the various legislatures. Does it mean that the party's entitlement to its amount for the coming year is determined on 1 April, irrespective of changes in its representation (elections, floor crossing, etc) during the course of that year? Or can the allocations change between two instalments in the same financial year? The fact that the 2004 election was held in April meant that the first instalment after the election overlapped neatly with the first instalment of the new financial year. The same applied to changes in representation and therefore funding allocations after the floor crossing in the national and provincial government spheres in April 2003 (interview, ChaplogLouw \& Hendrickse 2004).

\section{Management OF THE Fund}

The management framework of the fund is determined by the regulations drafted by the joint parliamentary committee. The annual parliamentary allocation is incorporated in the budget of the Department of Justice and Constitutional Development, presented to Parliament for approval as part of the national Budget. The IEC has, therefore, no discretion in respect of the criteria for managing and taking decisions about the fund (interview, Chaplog-Louw \& Hendrickse 2004).

An interesting aspect of the IEC's management of the fund is, however, the correlation between the parliamentary allocation to the fund and the eventual allocation made to the political parties. It is presented in Table 4.

The allocations to the parties were always less than the parliamentary allocation, except in 2001/2002 and in 2002/2003. On average the parliamentary allocation increases incrementally by 5 per cent per annum, while the percentage increases (or decrease) in the allocation to parties show no pattern. There were above average increases in the financial years 2001/2002 and 2002/2003. 
Table 4

\begin{tabular}{|c|c|c|c|c|}
\hline $\begin{array}{c}\text { Financial } \\
\text { Year }\end{array}$ & $\begin{array}{c}\text { Number of } \\
\text { Parties }\end{array}$ & $\begin{array}{c}\text { Parliamentary } \\
\text { Allocation (R) }\end{array}$ & $\begin{array}{c}\text { Allocation to } \\
\text { Parties (R) }\end{array}$ & $\begin{array}{c}\text { Increase/decrease } \\
\text { (\%) }\end{array}$ \\
\hline $1998 / 1999$ & 8 & 53000000 & 52103000 & - \\
\hline $1999 / 2000$ & 13 & 55650000 & 54708147 & 5,0 \\
\hline $2000 / 2001$ & 13 & 57880000 & 57880000 & 5,7 \\
\hline $2001 / 2002$ & 13 & 60983000 & 62886155 & 8,65 \\
\hline $2002 / 2003$ & 13 & 63683000 & 67405856 & 7,19 \\
\hline $2003 / 2004$ & 20 & 66653000 & 66604023 & $-1,19$ \\
\hline $2004 / 2005$ & 12 & NA & 70844436 & 6,37 \\
\hline
\end{tabular}

We can also look at the fund's annual surpluses or deficits and the balance in its accounts (Table 5) to explain the IEC's style of management.

\section{Table 5}

\begin{tabular}{|c|c|c|}
\hline Financial Year & Surplus/(Deficit) (R) & Balance (R) \\
\hline $1998 / 1999$ & 759940 & 759940 \\
\hline $1999 / 2000$ & 2998042 & 3757982 \\
\hline $2000 / 2001$ & 1765415 & 5576386 \\
\hline $2001 / 2002$ & $(1869665)$ & 3706721 \\
\hline $2002 / 2003$ & $(3479050)$ & 227671 \\
\hline $2003 / 2004$ & 45476 & 273147 \\
\hline
\end{tabular}

SOURCE: IEC 2001, p 39; IEC 2002A, p 55; IEC 2002B, pp 57-58; IEC 2002C, pp 57-58; IEC 2003, pp 55-56; IEC 2004, pp 69-70

The two deficits in 2001/2002 and 2002/2003 and the above average increases in allocations to the parties in those years are explained by the high interests received in 1999/2000 and 2000/2001. In both these years there was a substantial surplus and a very healthy balance on the accounts. The 'over'-spending in 2001/2002 and $2002 / 2003$ was intended to appropriate the accumulated interests. In 2003/2004 the fund was managed in such a manner that a small surplus was declared in order to settle on a balance of about R250 000 per year. This management intervention required a decrease of 1,19 per cent in party allocations between 2002/2003 and 
$2003 / 2004$, while the parliamentary allocation continued to increase by almost five per cent.

These aspects of fund management require discretionary decision-making and it could not be established who was responsible for taking these decisions. It is probable that the IEC managers played an important part in the decisions.

Taking cognisance of the fact that the IEC is responsible for the fund's management and administration, but that the parliamentary allocation is channelled through the Department of Justice and Constitutional Development's budget, while a joint bicameral parliamentary committee is responsible for its statutory aspects, the question can be posed: is there a mechanism whereby the represented political parties can interact with the IEC in relation to the fund? IEC officials indicated that no special liaison bodies exist within the IEC to perform such a function. According to Michael Hendrickse, the only available institutional mechanism is the Party Liaison Committee (PLC), situated in the IEC's Voting, Democracy Development and Liaison Department. Between general elections each of the represented parties has a seat on the PLC, while, during election periods, all the parties registered for participation are represented on the committee. The IEC could not recall any PLC meeting at which any aspect of the fund was raised by any party. At the time of the 1999 general election the United Democratic Movement complained in the PLC of the fact that it had no access to public funding because it had been formed after the 1994 election and did not qualify as a represented party. This move suggests that parties do not perceive the IEC as the real decision-maker in relation to the fund and public funding in general. It is, however, difficult to determine where the real locus of decision-making lies, and how the parties relate to it.

Another aspect of the IEC's fund management is that it does not have real powers to enforce the Act and lacks the statutory powers to enforce credible accountability. IEC officials refer specifically to the overlapping forms of party funding. For instance, parties receive funding from other sources to enable them to establish and maintain constituency offices. Because parties are not required to place the public funding they receive in trust accounts, it is impossible for auditors or persons outside the parties to link expenditure items to particular income sources. This enables political parties to engage in inventive bookkeeping between different accounts. The Act does not prevent them from arbitrarily deciding which expenses to include in their public funding account and which to transfer to other accounts. Malpractices in this respect can only be detected by their external auditors, but the IEC lacks the powers to perform independent audits.

IEC personnel who manage the fund have also expressed their concerns about a widely-held suspicion that political parties utilise their public funding as security for bank credit. Though the Act and Regulation do not explicitly prohibit such a practice, the IEC has doubts about its ethicality (interview, Chaplog-Louw \& Hendrickse 2004).

Taking into account the above-mentioned reservations about the parties' effective and credible public accountability, the fund's regulations (1998, pp 2-3) 
identified six descriptive expenditure categories for the utilisation of public funds. Parties must organise their annual audited financial statements in accordance with these categories. Table 6 indicates the parties' financial practices during the 2003/ 2004 financial year (these are relevant to the 2004 election).

\section{Table 6}

\begin{tabular}{|c|c|c|c|c|c|}
\hline & ACDP & ADP & ANC & AZAPO & $\mathrm{CP}$ \\
\hline Allocation for the year & 1404822 & 72274 & 42573853 & 72274 & 198002 \\
\hline Less: total expenditure & (1550 278) & $(60823)$ & $(42572$ 100) & (72 837) & (198 026) \\
\hline 1) Personnel Expenditure & 453000 & 6152 & 21556123 & 12600 & 156077 \\
\hline 2) Accommodation & 150 & - & 59805 & - & - \\
\hline 3) Travel & 112978 & - & 614781 & 694 & - \\
\hline 4) Arrangement of & 138255 & 3931 & 13510 & - & - \\
\hline \multicolumn{6}{|l|}{ Meetings, Rallies } \\
\hline 5) Administrative & 404349 & 35773 & 5482659 & 59543 & 35163 \\
\hline 6) Promotion and & 418187 & 14638 & 14845222 & - & 1500 \\
\hline \multicolumn{6}{|l|}{ Publications } \\
\hline Fixed Asset Expenditure & 23359 & 329 & - & - & 5286 \\
\hline Unspent money at & $(145456)$ & 11451 & 1753 & (563) & (24) \\
\hline \multicolumn{6}{|l|}{ year-end } \\
\hline Plus: interest and other & 14160 & 3 & 3802 & 461 & 32 \\
\hline \multicolumn{6}{|l|}{ income } \\
\hline \multirow[t]{2}{*}{ Surplus/(deficit) } & (131 296) & 11454 & 5555 & $(102)$ & 8 \\
\hline & DA & FA & FF & IAM & ID \\
\hline Allocation for the year & 7087154 & 342551 & 933740 & 72274 & 270277 \\
\hline Less: total expenditure & (6949 563) & $(359451)$ & (1940 798) & (71 096) & $(257609)$ \\
\hline 1) Personnel Expenditure & 4934463 & 64175 & 353053 & 13802 & - \\
\hline 2) Accommodation & - & - & 12795 & - & - \\
\hline 3) Travel & 21798 & 96034 & 88305 & 7088 & - \\
\hline 4) Arrangement of Meetings, & - & - & 7775 & 2515 & 257000 \\
\hline \multicolumn{6}{|l|}{ Rallies } \\
\hline 5) Administrative & 1857816 & 199242 & 839615 & 12283 & 609 \\
\hline 6) Promotion and Publications & 135486 & - & 639255 & 35408 & - \\
\hline Fixed Asset Expenditure & - & - & - & - & - \\
\hline \begin{tabular}{|l|} 
Unspent money at year-end \\
\end{tabular} & 137591 & $(16900)$ & $(1007058)$ & 1178 & 12668 \\
\hline Plus: interest \& other income & 15352 & 110 & 33079 & - & 56 \\
\hline Surplus/(deficit) & 152943 & $(16790)$ & $(973979)$ & 1178 & 12724 \\
\hline
\end{tabular}




\begin{tabular}{|c|c|c|c|c|c|}
\hline & IFP & MF & NA & NLP & NNP \\
\hline $\begin{array}{l}\text { Allocation for the year } \\
\text { Less: total expenditure }\end{array}$ & $\begin{array}{r}5050841 \\
(5111225)\end{array}$ & $\begin{array}{r}371830 \\
(389658)\end{array}$ & $\begin{array}{r}72274 \\
(72326)\end{array}$ & $\begin{array}{r}202480 \\
(202273)\end{array}$ & $\begin{array}{r}4702101 \\
(4723160)\end{array}$ \\
\hline 1) Personnel Expenditure & 3159309 & 19950 & 71845 & 113161 & 1224106 \\
\hline 2) Accommodation & - & - & - & 11900 & 35740 \\
\hline 3) Travel & 84714 & - & - & 8050 & 240278 \\
\hline $\begin{array}{l}\text { 4) Arrangement of Meetings, } \\
\text { Rallies }\end{array}$ & 195442 & - & - & 16145 & 227825 \\
\hline 5) Administrative & 1354148 & 169397 & 481 & 7258 & 1179875 \\
\hline 6) Promotion and Publications & 52053 & 196652 & - & 45759 & 1815336 \\
\hline Fixed Asset Expenditure & 265559 & 3659 & - & - & - \\
\hline Unspent money at year-end & $(60384)$ & $(17828)$ & (52) & 207 & $(21059)$ \\
\hline $\begin{array}{l}\text { Plus: Interest and other } \\
\text { income }\end{array}$ & 22678 & 46 & 5 & 35 & - \\
\hline \multirow[t]{2}{*}{ Surplus/(Deficit) } & $(37706)$ & $(17782)$ & $(47)$ & 242 & $(21059)$ \\
\hline & PAC & PDP & UCDP & UDM & Total \\
\hline Allocation for the year & 610995 & 227281 & 535951 & 1779752 & 66653000 \\
\hline Less: Total expenditure & (791 629) & $(218852)$ & (539 895) & $(1655704)$ & $(67737303)$ \\
\hline 1) Personnel Expenditure & 413874 & 624 & 164497 & 356597 & 33073408 \\
\hline 2) Accommodation & - & 2256 & 6503 & 37360 & 166509 \\
\hline 3) Travel & 20092 & 14035 & 40523 & 277378 & 1626748 \\
\hline $\begin{array}{l}\text { 4) Arrangement of Meetings, } \\
\text { Rallies }\end{array}$ & 61991 & 30041 & - & 89499 & 1043929 \\
\hline 5) Administrative & 209632 & 6714 & 207191 & 471939 & 12533687 \\
\hline 6) Promotion and Publications & 82689 & 165182 & 108314 & 422931 & 18978612 \\
\hline Fixed Asset Expenditure & 3351 & - & 12867 & - & 314410 \\
\hline Unspent money at year-end & $(180$ 634) & 8429 & (3944) & 124048 & $(1084303)$ \\
\hline $\begin{array}{l}\text { Plus: Interest and other } \\
\text { income }\end{array}$ & 188 & 105 & 1842 & 5657 & 97611 \\
\hline Surplus/(deficit) & $(180446)$ & 8534 & (2 102) & 129705 & (986 692) \\
\hline
\end{tabular}

SOURCE: ANNUAL REPORT OF THE FUND, PREPARED By THE IEC (IEC 2004, P 76)

The fact that the parties' expenditure is structured into six categories (plus a fixed asset expenditure), means that the external observer or the public can hardly gain a sense of the real nature of how the moneys have been used. It is even more of a problem if one takes into account the broad purposes of the funds set out in Article $5(1)(b)$ of the Act. In the end the parties' integrity, and not the statutory provisions, is the only guarantee that the moneys have been correctly utilised. 


\section{Contentious Aspects of THE Funding}

Two categories of parties excluded from public funding in South Africa are those not represented in any national or provincial legislatures and those represented only in local or municipal councils. Because only parties that are represented may receive funds parties that are formed between elections experience a systemic bias and are at a disadvantage when they fight their first election. (That was the predicament of the UDM in 1999.) The counter-argument might be that if they have sufficient popular support, the two opportunities for floor crossing in the second and fourth years of a legislative term will provide them with the chance to receive some representation before an election, and that public funding for them will be adjusted in response to that situation. Floor crossing cannot, however, be considered a reliable barometer of public opinion or general electoral support.

The Independent Civic Organisation of South Africa (ICOSA) raised the problem of the exclusion of local parties in response to its disqualification from participation in the 2004 election. In its view, the exclusion of local parties from funding is discriminatory and unfair, and it therefore calls for an amendment to the Constitution. It also calls for 'equal funding for party elections campaigns to promote multi party democracy' (Affidavit 2004, p 2; Letter, Dhlamini 2004, p 3). In principle, the exclusion of local parties appears to be an anomaly and contradictory to the purpose of public funding. The special electoral system used in the local government sphere would, however, complicate practical implementation of funding. Half the seats in municipal councils are filled by a system of proportional representation and party lists. Public funding for them might still be manageable. The other half are filled by ward representatives who may be individual, independent candidates. By-elections, as well as the two floor crossings per legislative term, may also complicate changes in representation more than they do those at the national and provincial levels. Public funding for them would be senseless and would pose an administrative nightmare. Alternatives to funding, such as the free use of public facilities for electioneering, might be more feasible.

\section{CONCLUSION}

The funding - whether private or public - of political parties poses major challenges for the public, for watchdog institutions in civil society, and for statutory bodies responsible for enforcing party accountability. Access to financial resources will always be considered by contesting parties as the crux of their success or failure. The public tends always to be suspicious that big donors - mainly corporate businesses - will gain a disproportionate advantage in public decision-making processes, which approximates to corruption or undue influence.

Regulating party funding is, therefore, a compromise option. But regulation can engender credibility and trust only if loopholes are closed and one way of doing so is to regulate both public and private funding. European practices involve 
far more regulatory interventions and limitations than do those in South Africa. In addition to the fact that South African lawmakers are not willing to compromise the privacy of their donors, they might also be sensitive about being seen to limit the freedom of political competition. The belief that African governments are interventionist in order to hamstring their opponents might make funding regulations unpopular in ANC circles, despite the fact that similar regulations operate successfully in the European context.

The main characteristic of public funding in South Africa, and its administration by the IEC is that the IEC has almost no powers to enforce the regulations. Public accountability assumes a prescribed form, but its content cannot be verified independently. For the smaller parties public funding provides probably more of a support base than it does for the larger parties, which can rely more on private donations. In this respect, public funding does make a contribution to multiparty participation, especially in a developing political system.

\section{- REFERENCES —}

Publications and documents

African Union. 2003. African Union Convention on Preventing and Combating Corruption. Adopted by the $2^{\text {nd }}$ Ordinary Session of the Assembly of the Union, Maputo, 11 July 2003 (mimeo).

Austin, Reginald and Maja Tjernström (eds). 2003. IDEA Handbook on Funding of Political Parties and Election Campaigns. Handbooks Series. Stockholm: IDEA Committee of Ministers. 2003. Council of Europe. 'Recommendation Rec (2003)4 of the Committee of Ministers to Member States On Common Rules Against Corruption in the Funding of Political Parties and Election Campaigns'. Adopted by the Committee of Ministers on 8 April 2003 at the $835^{\text {th }}$ meeting of the Ministers' Deputies (mimeo).

(www.vaalit.fi/uploads/oifo2pfn62klmg.pdf)

Dhlamini, L S. 2004a. Affidavit - Appeal to Parliament, the IEC and SALGA by L S Dhlamini, President, Independent Civic Organisation of South Africa (mimeo).

- 2004b. Letter to the South African Human Rights Commission, 22/6/2004:

L S Dhlamini (ICOSA President) (mimeo).

European Conference. 1998. 'Trading in Influence and Illegal Financing of Political

Parties'. $3^{\text {rd }}$ European Conference of Specialised Services in the Fight Against Corruption, Madrid, 28-30 October 1998.

Idasa. 'Party-funding: avoiding the slipping slope' (www.idasa.org.za/ output_details.asp?RID $=527 \& O T I D=4 \& T I D=1$ ), accessed 04/09/ 02

IEC. 2001. 'Report regarding the Management and Administration of the Represented Political Parties' Fund during the financial year 1 April 1998 to 31 March 1999 in terms of Section 8 of the Public Funding of Represented 
Political Parties Act, 1997 (Act 103 of 1997)'. Annual Report 1998/1999. PR46/ 2001. Pretoria.

IEC. 2002a. 'Report regarding the Management and Administration of the Represented Political Parties' Fund during the financial year 1 April 1999 to 31 March 2000 in terms of Section 8 of the Public Funding of Represented Political Parties Act, 1997 (Act 103 of 1997)'. Annual Report 1999/2000. PR142002. Pretoria.

—. 2002b. 'Report regarding the Management and Administration of the Represented Political Parties' Fund during the financial year 1 April 2000 to 31 March 2001 in terms of Section 8 of the Public Funding of Represented Political Parties Act, 1997 (Act 103 of 1997)'. Annual Report 2000/2001. PR152002. Pretoria.

- 2002c. 'Report regarding the Management and Administration of the Represented Political Parties' Fund during the financial year 1 April 2001 to 31 March 2002 in terms of Section 8 of the Public Funding of Represented Political Parties Act, 1997 (Act 103 of 1997)'. Annual Report 2001/2002. PR1472002. Pretoria.

- 2003. 'Report regarding the Management and Administration of the Represented Political Parties' Fund during the financial year 1 April 2002 to 31 March 2003 in terms of Section 8 of the Public Funding of Represented Political Parties Act, 1997 (Act 103 of 1997)'. Annual Report 2002/2003. PR68/ 2003. Pretoria.

- 2004. 'Report regarding the Management and Administration of the Represented Political Parties' Fund during the financial year 1 April 2003 to 31 March 2004 in terms of Section 8 of the Public Funding of Represented Political Parties Act, 1997 (Act 103 of 1997)'. Annual Report 2003/2004. PR1162004. Pretoria.

- 2004. 'Public funding of represented political parties - allocation for 2004/ 2005: Schedule A'. Pretoria: IEC (mimeo).

Mail \& Guardian online. 2004. 'Who's funding whom?', 2 September. www.mg.co.za/ Content/13.asp?ao=24140\&t=1), accessed 2 September 2004.

Mamaila, Kathu. 2004. 'Business \& political party funding'. The GIBS Review vol 3. University of Pretoria, March. (www.gibs.co.za/Review/Issues / GIBSReview\%20March\%202004.pdf)

Msomi, S'thembiso. 2004. 'The funding party'. Sunday Times 7 March. (www.suntimes.co.za/2004/03/07/business / columns / columns4.asp), accessed 2 September 2004.

Naidoo, Prakash. 2004. 'Privacy and the right to know'. Financial Mail (http:// secure.financialmail.co.za/03/1114/currents/bcurrent.htm), accessed 2 September 2004.

Nduru, Moyiga. 2004. 'Politics - South Africa: Campaign financing in the spotlight'. Inter Press Service News Agency (http: / / ipsnews.net/ interna.asp?idnews=23259), accessed 2 September 2004. 
Parliamentary Assembly. 2001. Council of Europe. 'Financing of political parties'. Recommendation 1516.

SADC. 2004. 'SADC Principles and Guidelines Governing Democratic Elections'. Adopted by the SADC Summit, Mauritius, August (mimeo).

(www.iss.co.za/AF/RegOrg/unity_to_union/pdfs/sadc/elecprinciples.pdf) ThisDay. 2003. 'Court bid to expose political party funding', 27 October. (www.legalbrief.co.za/view_1.php?artnum=12787), accessed 2 September 2004.

Transparency International. 2003. Political party funding campaign, South Africa. (www.transparency.org/toolkits / 2002/ch3-election-campaign/ 3pol_party_funding_campaign_southafrica.pdf)

Wa Afrika, Mzilikazi, Andre Jurgens and Jessica Bezuidenhout. 2004. 'Mining magnate behind R500 000 gift to ANC'. Sunday Times 25 January. (www.suntimes.co.za/2004/01/25/news/news10.asp), accessed 2 September 2004.

\section{Legislation}

Electoral Act 73 of 1998.

Public Funding of Represented Political Parties Act 103 of 1997. Government Gazette 390 (18157), 19 December. Cape Town: Government Printer

Regulation. 1998. Regulation under Section 10(1) of the Public Funding of Represented Political Parties Act 1997. Government Gazette - Regulation Gazette 401(19478 (no 6350), 20 November. Pretoria: Government Printers

\section{Interviews}

Chaplog-Louw, Geraldine and Michael Hendrickse. Interview with the author, Election House, Pretoria, 29 September 2004 (Chaplog-Louw is the Manager: Budget and Political Party Funding, IEC)

February, Judith. 2004. Interview with the author, 29 October 2004 (February is the head of Idasa's Political Information Monitoring Service - SA) 